\title{
Inscription of Foundation dated 970 AH / 1562 AD at Jehar Bakr Mosque in the City of Bukhara
}

\section{Inscription of Foundation dated 970 AH / 1562 AD at JeharBakr Mosque in the City of Bukhara \\ Dr/ NohaGamil Mohamed Ghaly \\ Lecture in Islamic dept., Faculty of Archaeology, Cairo Univ. e-mail: Nohaghaly51@yahoo.com}

\begin{abstract}
The buildings of the city of Bukhara, like the rest of the buildings in Central Asia, abound with numerous written inscriptions with religious and registration contents, among which are a number of foundational inscriptions and inscriptions of reform and renewal. Through these inscriptions, the role played by the sultans and princes in the political as well as the social life can be clarified, besides their relation with clergy and how they try to get close to them.

One of these buildings connoting an inscription of foundation (PI. 1) is considered as a remarkable one in Bukhara's buildings. This inscription contains many titles that show the political orientations of Bukhara's government in that period. Also, it connotes the date of the accomplishment of the building. As a matter of fact, this study is concerned with dealing with this inscription in terms of form and content and linking the content to the circumstances and political events of that period.
\end{abstract}

Keywords: Bukhara, Jehar Bakr, Mosque, Inscription, Timurids.

\section{The Inscription of Foundation}

The inscription of Foundation occupies the main entrance stone (PI.2) of the Jahar Bakr Mosque, which is located on the eastern facade, within a rectangular frieze of ceramic mosaics (Ghaly, 2011, p. 58). The inscription is written in Thuluth calligraphy (Gharmat, 2016, p.39), in white on turquoise background. In between the letters vertex, another inscription is executed in floral Kufic calligraphy, in light blue on the same turquoise background. (PI. 3, 4, 5, 6, 7, 8).

The Inscription's Text (Fig. 1A, B, C, D, E, F)

" قد وفق لبناء هذه البقعة و اتمامها حضرت كردون بسطت سدره منزلت عدالت قباب (مآب )حكومت نصاب ايالت بناه

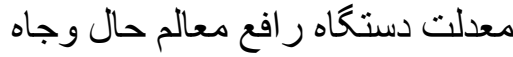

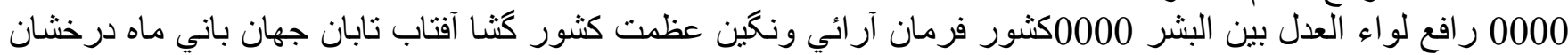

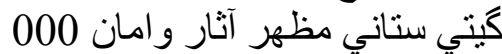

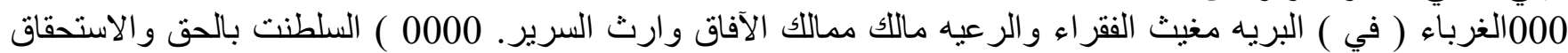
و المتمثل ان الحكم لله ايام 0000 بالعدل والاحسان ابو الغازي اسكندر بهادر خان لاز الت رائ رايات دولته مرفوعة الى قلى قلمة 00000( بسى بر سر خلق باينده دار / بتوفيق احسان دلش زندهدار ) بسعي بنده دركاه خليفه نعمه الله بأتمام رسبد في سنه

\section{The Inscription's Translation / Transliteration}

سبعين وتسعماية 970

The construction and completion of this spot was accomplished by hadrat bastat alfulk , manzilat alsidra , marjie aleadalat, nasib alhukumat, malja alwilayat, jihar aleadl, rafae maealim alsaeadat waljah 


\section{Journal of Faculty of Archaeology - Volume 232020}

rafe liwa' aleadl bayn albshr.... zaynah hukkam albilad, fas khatam alazm , fatih albilad, alshams almushriqa , bani ala'lam, alqamar almunir fatih aldunya , mazhar alathar wal'aman ....

....alghurba'( fi ) albariya mughith alfuqara' walraeya malik mamalik alafaq $w$ arth a'rsh alsaltana bialhaqi walaistihqaq walmutamathil 'iina alhukm lilah 'ayam .... bialeadl wal'iihsan 'abu alghazii 'iiskandar bihadir khan lazalt rayat dawlatih marfueatan 'iilaa qimat alsama'

.... (May he live long upon the heads of creation / and may his heart always stays alive with good luck and charity) It was accomplished with the effort and supervision of Abd Balat AlKhalifa Neamatullah in the year 970

\section{Analytical Study of the Inscription \\ First: In Terms of Form}

The inscription is executed in clear Thuluth script (al-Qalqashandi, 1913, part 3, p. 55) (Arslan, 2007, p. 219) (Fadhili, 2006, p. 266), which is considered as a kind of Thuluth script. It also represents the last phase of Thuluth script evolution, which went through four different stages that start with the oldest Thulth and end with the clear Thuluth. The font of the inscription under study was distinguished by the multiplicity of levels in one inscription, which created a kind of difficulty in reading. In fact, the multiplicity of the font levels became a feature of Thuluth script executed on the architectural buildings in Central Asia. Besides, it was not used alone on buildings, but was implemented in conjunction with some types of Kufic script in between the letters vertex and shafts (Ubaid, 2012, p.134). One of the most important technical features that characterized the Thuluth script is that the calligraphist has combined the characteristics of both Thuluth and Galie script together, which is represented in the susceptibility of composing the letters of the Thuluth, as well as the large size of its letters, moreover, its letters are not written with a letter like the regular Thuluth, but rather the letters are saturated and strong (Ubaid, Helal, 2013, p. 216).

The Thuluth script was ranked high on the Timurids buildings (771-906 AH / 1369-1500 AD) in Samarkand right after the Kufic script, such as the frieze on the eastern side of the south facade of the courtyard of Kur-Amir complex (807-808 AH / 1404 - 1405 AD), which is done in Thuluth script, along with its inscription of foundation. Subsequently, it was used during the Shaybanit era (906 - 1006 AH / 1500 - 1598 AD) as a continuation of the apparent development in the Timurid period. As an example; it was used in the inscription of foundation of Kojkunji Khan Mosque in the Ristan Square in Samarkand. However, it lacked precision in the late Shaybanit era, as some letters lost their apparent grace of the Timurid era and became rougher (Majdi, 2018, p. 287).

\section{The Kufic Script}

The Kufic script (Pope, 1983) (David, 1991) (Blair, 1998) (Jum`a, 1969) (Ubaid, 2012) represents the common denominator along with the Thuluth script implemented on Central Asian buildings since the Timurid era and has continued until the following historical epochs. 


\section{Inscription of Foundation dated 970 AH / 1562 AD at Jehar Bakr Mosque in the City of Bukhara}

It was used in between the letters vertex and shafts as it was implemented in conjunction with the inscription written in Thuluth script. In addition, engraver used several forms of Kufic script such as the primitive, leafy, floral, and interlaced Kufic script, the content of which is predominantly religious, and includes a repeated praising phrase reading "Allah Akbar", "God is great".

\section{Second: In Terms of Content}

The inscription was executed in four levels; in which the first three ones done in Thuluth Galei script, while the fourth one is done in different forms of Kufic script. The first, second, and third level of the inscription clarifies the name of the place, besides several titles; It numbered twenty-one titles in addition to the name of the architect, and the date of accomplishing written in both numbers and letters. The following is an analytical study of the content of these titles:

The Spot: "The construction and completion of this spot was accomplished by ...", the content and context of the text was clearly defined by using the term "spot", which represents the kindness, blessing and prasing for the location of this building. The reason for this is that the four spiritualists were all buried in the dome attached to this facility, where Abdullah Khan the second was interested in memorializing Khawaja Abu Bakr Saad by building the dome of the burial, the mosque and the school. He and his father Iskandar Khan used to call themselves the spiritual disciples of Sheikh Al-Islam in Bukhari Sheikh (Muhammad Islam Khawaja), the father of Khawaja Abu Bakr Saad, especially, Sheikh Muhammad Islam was the one who helped Abdullah Khan to ascend the throne, by eliminating Burhan Khan where they secretly infiltrated to Burhan Khan palace at night and killed him with the assistant of Bukhara people. Abdullah Khan sat on the throne as he was with him in most of the wars he fought (Akram, 1970, p. 102). And the statement in its entirety indicates that the process of starting and completing construction took place during the era of "Abdullah Khan" (964, $991 \mathrm{AH} / 1557,1583$ CE) (Ahmedov, 1996, P336).

Hadrat: This word means "beside something". For example; we say "beside the house". Also, it gives the meaning of the presence (Al-Farahidi, 1414, pp. 394,395). It is one of the dominant titles in Sufism, as it was mentioned on their facilities, such as the dome of al-Sayda Arefa "sheikh Bahaa al-Din Nakshaband's mother" (10th century AH, $16 \mathrm{AD})$ as "kashf alhaqayiq mazhar aldaqayiq hadratan biha' aldiyn". Also, it was mentioned on the funereal dome of Khojah Ismat Allah Al Bukhari (10th century AH / 16AD) with the formula "huna marqad hadarat mawlana khuajah fakhar aldiyn....", and the tombstone of sheikh Bahaa Al-Din Naqshband, in the form of "hdha almarqad almunawar lihadrih alshaykh....", and on the monastery of Faizabad (11th century AH / 17AD), on the tombstone of the cenotaph in the southern side in the form (....alshaykh almurshid alnqshibndiu hadarah....). 


\section{Journal of Faculty of Archaeology - Volume 232020}

And the compound of Mawlana Abi Hafs Al-Kabeer Al-Bukhari (13th century AH / 19AD) witnessing the tomb in front of the cenotaph (....almahadath alfaqyh hadarah 'abu hafs 'ahmad bin hafs....).

On the other hand, the word "al-hadra" in the language means annihilation. It was also used as an honorary title for the first one who began to write about the caliph. Archaeological inscriptions and historical documents indicate that it was used in the fourth AH / tenth AD century, and was used by the Seljuk Sultans (Barakat, 2000, p. 208). As a matter of fact, this was one of the ancient titles used between the caliphs, and was mentioned as the supreme hadra, and the high hadra. It was also used in the decrees issued from the sultan to some kings, and what was written by dignitaries of the state (AlQalqashandi, 1913, vol. 5, p. 498).

Bastat Alfulk: publish it, which means the amplitude, and the object spread over the ground. And "basta" in the country, meaning that he walked in length and breadth. It also means the wide land (Al-Jawhari, 2005, p. 91), and the title (Basta Al-Falak) indicates the extent of his knowledge of this science that he obtained, in addition to his scientific interests such as building schools. The word "Basta" was mentioned as "Basta al-Alam" with the inscription of "Alag Beck" (Ubaid, Hilal, 2013, p. 212).

Manzilat Alsidra: One of the Sufism titles, which reflects the purity of the soul, and makes a person pious, as the "sidra" is the highest point in heaven, thus, it gives the significance of the ruler's stature, as he reaches the level of the righteous and the saints.

Marjie Aleadalat: One of the titles of Sufism that implies tenor of spreading justice everywhere, and allocates this authority to the sultan who is entrusted with the execution of the ruling. This means that he rules with justice and is aware of all legal rulings, as he is the refuge of every wronged person seeking justice, neither does he oppress anyone, nor he accepts injustice.

Nasib Alhukumat: it means that he is a resident of the government's orders, the executor of its instructions, the guardian of its entity, composition and reputation with the people, and the executor of all his job duties, and the supervisor of that, whose existence is a reason for the survival of this government and the performance of its job in a full manner.

Malja Alwilayat: A shelter here came in a combined form, as it came attached to the owner of the sword and the flag, the shelter of horses and the crow. It is one of the honorary titles that were found rare, perhaps only on one model, and it was installed by Sultan Hamza Abu Al Khair Bahadur Khan in Samarkand 917 AH (Majdi, 2018, p. 354). While the "wilaya" means granting love and victory, as God, glory be to Him, if He protects a worshiper, He loves him, supports him, praises him, and honors him. The Qur'an declared that every believer is true to faith, is protected from God (Abdul-Khalik, 1984, p. 177), God Almighty said: \{God is near unto those who have faith, taking them out of deep darkness into the light - whereas near unto those who are bent on denying the truth are the powers of evil that take them out of the light into darkness deep: 


\section{Inscription of Foundation dated 970 AH / 1562 AD at Jehar Bakr Mosque in the City of Bukhara}

it is they who are destined for the fire, therein to abide\} [Al-Baqarah: 257].

Jhar Al-Adl: Perhaps the engraver wanted to show that the ruler among his people applies the four doctrines, as this facility was built during the reign of Abdullah Khan to commemorate his father Iskandar Khan. One of the Bedouin traditions, when someone ascends the throne, he must be held in a white fur by, four sides representing four Bedouin tribes, but Abdullah changed this. Instead of the Bedouins carrying these four sides, it was carried by the heads of the Sufi schools in Bukhara. This was that he was trying to combine the habits of polytheists of the Bedouins and the Islamic spirit prevailing in his country. (Bartold, 1996, p. 216). Perhaps this was clarified through this inscription by the engraver, in order to show the Islamic spirit spread through the four doctrines applied since the reign of Iskandar Khan and his son Abdullah Khan.

Rafae Maealim Alsaeadat Waljah This title shows the extent of the prosperity that Syr Darya has achieved in all areas during the reign of Iskandar Khan and by his son Abdullah Khan; from building khans and other charitable institutions to the nourish of trade, which comes as a result of improving roads and water tanks and repairing coinage. Moreover, the agriculture and science flourished, as Iskandar Khan and his son Abdullah Khan were powerful shepherds, working to spread culture among their people and work for their well-being as well as their interest in sports and building gardens (Arminius, 1987, pp. 350, 352).

Rafe Liwa' Aleadl Bayn Albshr: Raised the banner of justice among humans: Rafe: a subjective from the verb "raised". The banner: a feminine Arab name, and may be a masculine name as well, which means the flag.

As for justice in language: justice is unlike oppression, which is the intent in matters, and what has arisen in the soul is righteous. Whoever adjusts justice, it is fair in terms of justice. It is said: he, who arise justice in a case, is a fair person. The ruler spreads justice (Ibn Manzur, 1994, folio (11/430). The specific meaning of justice is applying fairness in its appropriate position, time, without any excess, no default, no delay (Al-Jahiz, AlMansoob, p. 28). And this title means that Abdullah Khan announced justice and professed it among the parish.

Zaynah Hukkam Albilad: zain in language is the opposite of something (AlQalqashandi, 1913, p. 52). The engraver indicates that the period of Iskandar Khan is a manifestation of glory that surrounds the throne of the country, which reached that stature due to the conquests of his son Abdullah Khan, whose popularity raised to the level that ambassadors delegation came from China loaded with precious gifts, and others sent delegations to congratulate him on his victories (Arminius, 1987, pp. 351, 352)

Fas Khatam Alazm: The meaning of the ring of the bone; is the ring attached to the finger until it almost touches the bone from the strength of its tightness on the finger, and therefore it is never separated from its owner. 


\section{Journal of Faculty of Archaeology - Volume 232020}

The ring is the sign of reign, thus, the engraver might wanted to reflect that the ruler is attached to his reign, like the ring is attached to the finger. And while the jewel that the ring is studded with, is the most valuable part of it, besides, the ring lobe is the one on which the names and titles of the sultans are engraved, therefore, the engraver also shows the significance of the ruler, and that no one can replace him in power or reign.

Fatih Albilad: fatih: a name "subjective" of the verb conquer. Conquered the country means that the ruler entered it after he overcame its people and subjected it to his authority. The engraver indicated that this title shows the regional conquered countries by Abdullah Khan, as he conquered Bukhara then Samarkand where he established himself at the head of the army with which he intended to return his Shibani state to what it was. The borders of Khanate Bukhara extended during the era of Abdullah Khan to the inhabited areas in Turkestan in the north (Arminius, 1987, p. 340).

Alshams Almushriqa: This title indicates that the title holder, Iskandar Khan, in relation to the sect expressed as the Sufism, is like the sun in appearing and giving its light and life to the world (Barakat, 2000, p. 38. This title continued to be used in various forms during the Shaiban era including the composition of Abu Al-Fath Muhammed AlShaibani Khan in the compound of Al-Shaibanan tombs on 916 AH, 1510AD (Majdi, 2018, p. 126) in the form of (.... Sun of the Sky Al-Khanya ...), and the same title (the Rising Sun) was mentioned in the mass of the main entrance of the Sheer Ghazi Khan School of Khiva (1132 AH / 1720AD), as (King of the world Justice, the invading lion, the rising sun ....) (Ubaid, Hilal, 2013, 165, 167).

Bani Al-Aalem: Bani is the subject of build (bana) since he was an expert of construction, and although the word banih (builder) indicates that he was the one who funded the construction and ordered it (Barakat, 2000, p. 372), in this inscription Iskander Khan did not build it, but his son Abdullah Khan to commemorate his memory. AlAalem: One of the titles of the Sultan, which is the opposite of ignorant, is in fact only one of the titles of scientists, but it was in fact one of the common titles between the lords of swords and pens. However, they used it to glorify the kings (Al-Qalqashandi, 1913, pp. 19, 20), and in this case it was often synonymous with (the worker) and (with the just), and it was mentioned in the inscriptions in the titles of these different denominations on the Khaqan Tatgh Khan Ibrahim on coins in $457 \mathrm{AH}$ of Ozkand (alBasha, 1984, p. 390). Perhaps "bani al-aalem title was used to indicate that during the reign of Iskander Khan and the era of his son many architectural establishments with different functions were established as schools, mosques, khans, pools of water and rest areas for travelers along the distant roads in many different places and by using this title he may have wanted to claim public sovereignty over the whole world.

The title Bani was mentioned in various forms in some Timorese establishments, including the Mirza Elgh Bek School (Bani Mabany Al-Elm wal Ehsan) in the middle apse of the entrance block, which refers to many architectural establishments with different functions established by Elgh Bek, which varied between educational and funerary establishments, both those constructed in Samarkand, Bukhara, or Sshahr Sabz. 


\section{Inscription of Foundation dated 970 AH / 1562 AD at Jehar Bakr Mosque in the City of Bukhara}

In this establishment the title al-Aalem was mentioned in the form of a compound (Sultan al-Aalem), as this title was mentioned in the Shaybani era in the form of (Malek al-Aalem) on the composition of (Abu al-Fath Muhammad Shaybani Khan) (916 AH / 1510AD) as ( .... Muhammad Khan, Malek al-Aalem) (Magdi, 2018, p. 130.)

Alqamar Almunir: one of the Sufism titles, as they imagine their poles as if they were moons or stars that illuminate the way to Allah, worship and goodness. This idea might be inspired from the word of the Messenger of Allah (peace and blessings of Allah be upon him), "my friends are like stars, who may lead you to be guided". It is a metaphor, which means that whoever is to be guided with the pole, as if they are guided by the moon and the star in the darkness or the sun in broad daylight."

Fatih Aldunya: The conqueror of the world is a metaphor for the ascendancy of Abdullah Khan and the expansion of his power over many different regions. He was able to control the northern part, and then subjugated Fergana, Kashgar, Dakhten, and seized Balkh in the south. He also gained the upper hand over the Persians, as he took over Herat, Mashhad, and Neyshabur (Arminius, 1987, pp. 340, 342).

Mazhar Alathar Wal'aman: Among the titles found on the monuments of Sufism. The word "appearance" in the sense of dignities and supernatural characteristics that are granted only to those who are close to God, and are pleased with them, thus, his Almighty give them superior capabilities not available to others. The word "safety" means that the person can protect his people with his super powers from enemies, especially that God includes them with his mercy and security for the sake of his love for this person, thus, they are the people who do not misery or fear as a result of his presence with them.

Alghurba'( Fi ) Albariya: He wanted to point out that he is a refuge for the strangers, the poor and others who did not find a guide or shelter, so they take refuge by his strength, and guided by his moderate opinion, as he is the refuge for every confused lost one. Concerning the word"al-bariya", it means the desert (The Glossary, 1989, 45). This word refers to the extension of the ruling power to the desert. This title was mentioned in the school of Shirdar (1029 - 1043 AH / 1619 - 1632 AD) (alnuqush al'iinshayiy, 2005, p. 11).

Mughith Alfuqara' Walraeya: al-mughith means the helper or the savior, which was used in the form of some composite titles, such as "mughith al-dawla wal din", and "mughith al-malhufen" (Al-Basha, 1984, p. 480). The engraver chose this title, for the many charitable works done during his reign such as; building the doss houses, healing houses, bridges and cisterns (Arminius, 1987, p. 350). Also, during his reign the schools were built for poor people, such as the school of Kasim Sheikh in Kerman (Bartold, 1996, p.103), as he spread generosity, and reassurance. 


\section{Journal of Faculty of Archaeology - Volume 232020}

During the Tumurid era, this title was mentioned but it came in a complex form in more than one formula, including the title of "Mugith al-Dunya wa al-Din", which was executed in the inscription of the Alleg Beck School. This title is considered one of the titles that combined the religious and secular attributes, and was found on the mass of the main entrance, and on the marble cenotaph of Mirza Alga Beck Baker Amir (alnuqush al'iinshayiy, 2005, p. 10) (Ubaid Hilal, 2013, p. 212).

Malik Mamalik Alafaq: The use of this title in Central Asia gives the meaning of the expansion of the king's power, that the ruler controls several kingdoms, not just one, and that his kingdom expands on many horizons, and lands. During his reign, Khorasan was annexed to his possession by his son Abdullah Khan, who succeeded in taking it from the hand of Shah Abbas bin Shah Tahmasb, as the borders of his state reached what he reached by Prince Taymur of the desert of Kabbak and Fath Al-Tagh (Bartold, 1996, p. 102). It is an honorary title, and it is one of the royal titles in the Islamic era. Perhaps the earliest use of it in the inscriptions was for Thahir al-Din of Teghtskin (Tghtikin), in the inscription of foundation dated $506 \mathrm{AH}$ in the Omar Mosque in Basra. Some words have been added to the title to form complex titles such as (Malik al-Bahrain, Malik Bilad Allah, Malik Rikab al-Omam). This title was given to Abi Al-Mudhafar Ibrahim bin Masoud in his text of Ghazni dating back to 492 AH (Al-Basha, 1984, p. 444) (Barakat, 2000, p. 54).

Arth A'rsh Alsaltana Bialhaqi Walaistihqaq: the engraver here wants to show the political side, by mentioning the word "Sultanate"; which means Bukhara, as Iskandar Khan assumed the throne of Bukhara in the year $935 \mathrm{AH}$ after his son Abdullah Khan summoned him from Jekarminah. However, the reins of affairs were in the hands of Abdullah Khan although he was not the official ruler (Ahmedov, 1996, P336). In point of fact, mentioning this phrase came after the disagreement between Abdullah Khan and Mir Muhammad Khan over the ruling of Bukhara, that Muhammad Khan took Balkh from Bukhara, thus, the Sufi elders from the Geoparians and the Naqshbandi rejected this deal. Therefore, this was a wrong decision taken by Abdullah to take over Bukhara under his power without counseling the Sufi sheikhs (Zohidullo, 2006, P. 338).

The Sultanate was also mentioned in a different form on some Timorese establishments, as it came in the form of the "Sultanate of Cairo" at the Elg Beck School in Samarkand, which has already become the seat of government since Prince Taymour (771 AH, 1369 AD) took it as his capital for his vast rule. It continued to be called the Sultanate even in the periods that the seat of the government was moved to another city in Herat or Bukhara (Ubaid, Hilal, 2015, p. 212). This formula was again mentioned on the tombstone of Abul Fatah Mohamed Shaybany Khan (907,920 AH/ 1501,1514 AD), dated 920 AH, 1514 AD (Babacan, Powell, Moamen, 1997, p. 5) in the form of “.... and the transfer of his honorable body and his gentle coffin to the Dar Al Sultanate of Samarkand" ( alnuqush al'iinshayiyat ,2005 , P. 8). Also, a formula for inheritance and entitlement was presented during the Shaybani era, in the centaph of Sultan Mahmud, at the compound of the Shaybani tombs, in 909 AH, 1503AD (Majdi, 2018, p. 124). 


\section{Inscription of Foundation dated 970 AH / 1562 AD at Jehar Bakr Mosque in the City of Bukhara}

Abul Ghazy: One of the titles of the swords owners, which is one of the incomplete nouns such as al-Qady (the judge), and it is only used as a high title without the ' $y$ ' (alQalqashandi, 1913, part 6, p. 21). It is also the name of the war in which the Prophet, may Allah's peace be upon him, was involved, naming those who were fighting in the name of Islam with it (al-Basha, 1984, p. 412). This title was given to Abdullah Khan, as he set himself on top of the army, with which he intended to return the Shibani state to its past borders, while the borders of Khan Bukhara extended during the reign of Abdullah to extend beyond the inhabited areas in Turkestan in the north (Arminius, 1987, p. 339). Abdullah Khan faced several wars with Babur Khan, but he triumphed over the latter, attempting to invade Transoxiana again. Abdullah Khan was able to defeat him completely, as he was able to seize Herat from Shah Abbas the Great and captured a number of the inhabitants to Bukhara (Arminius, 1987, pp. 340, 350).

Also, the title of Abul Ghazi was widely found on many architectural establishments in the Shaybani era, among which, for example, and not limited to, Abdullah Khan bin Iskandar Khan school in the form of (Abul Ghazi Abdullah Khan bin al-Khaqan bin alKhaqan). Also, it was found on some compositions of the Shaybani era, including tombstone of Kahrbanukhanim (943 AH / 1536AD) in the form of the late Abul Ghazi Taymur from the Shaybani era, and on the composition of Abul Ghazi Mahmoud Sultan (Babajan, Pawl, Moamen, 1997).

Iskander: The inscription refers to Iskander Khan bin Jani Bek, a Sultan succeeding his father in state in $935 \mathrm{AH}$. Iskander Khan had four children, the eldest of which is Abdullah Khan who became governor of Bukhara then called his father Iskander Khan back from Jekermeen and enthroned him. Iskander Khan then got isolated for worshipping until he died in $961 \mathrm{AH}$. The name Iskander Khan is one of the favored names and titles because it resembles Iskander al-Makduni, as it was also the name of Iskander Khan Ibn Imam Quli Khan (Akram, 1970, pp. 102, 104, 105).

The word Iskander was used in a different complex form in the Islamic era, as well as synonyms for it, like Iskander al-Zamaan " the Iskander of the time" and Iskander alThani "Iskander the second". The title Iskander and its various forms symbolize power. It resembles Sultan Iskander the Macedonian, whose armies reached India, and it simultaneously symbolizes the title Kafi men Allah and Mo'ayad bi Rouh Allah. Thus, it is evident that this title was related to the Sultan's strong power, as it was firstly given to Sultan Abi al-Mudhafar Muhammad bin Sam in 602 AH / 1206 in India. It was also given to Khwarizm Shah $610 \mathrm{AH} / 1214 \mathrm{AD}$ when his power extended and he eliminated the Seljuks in the east, then it was given to Kikhsro bin Kiqbad in 635 AH / 1238 AD after the Mughals overrode Khwarizm Shah and center of power shifted to the Seljuk Turks. Yet, the Mughals soon overrode Khwarizm Shah and the Seljuk Turks, thus the rule of the Islamic world at a time to the Mamluks in Egypt who were destined to withstand the Mughals' danger (al-Basha, 1984, pp. 158, 160). 


\section{Journal of Faculty of Archaeology - Volume 232020}

Bahader: A Turkish word of Mongolian origin derived from Bukhatir and its original meaning is brave or intrepid, then it has become an honorific title in the great Mughals court (Daerat al-Ma'ref, 1913, p. 141), and later on was adopted by the Timorese, attached to the names of many of their rulers and princes. This title was given to Abdul Aziz bin Alagh Bek as an honorary title, especially since he did not assume the sultanate and had no role in political life (Essam, 2013, p. 107) in the inscription of foundation of the main entrance of Shahzandeh court (838_839 AH / 1434-1435 AD) as (...Abdul Aziz Bahader...). During the Shaybani era, this title continued to be used, as it was given to "Abu Saeed bin Kojkunji Han" within the inscription recorded on his sarcophagus dated 940 AH, 1533 AD and Prince Yellenktosh, the governor of Samarkand who built the Sher Dar School (Ubaid, 2012, p. 198) (1029-1042 AH / 1619-1632 AD).

Khan: Al-Khan is a Turkish title given to the elder princes in the Turk tribes since the (1-2 AH / 7-8 AD) century, which means the president (al-Basha, 1984, p. 274), and it is originally an abbreviation for Qagan and in Arabic Khaqan. It appears that the word Khan (Arminius, 1987, p. 348) appeared around the end of the (4 AH / 10AD) century on the coins that the Ilkhanids struck, especially in the $5 \mathrm{AH} / 11 \mathrm{AD}$ century in texts related to this family. The word qagan or qa'an was not differentiated in the sense of the supreme ruler from khan, meaning the ruler of a separate region in the empire except in the Mughal era. In fact, in time, the word Khan replaced the words Qagan and Khaqan in common language. In the last centuries before the Mongol conquest, the Turkish word Khan was used in various different kingdoms to which the empire was divided (Daerat alMa'ref, 1913, s. 8, p. 204) by the Mughals in Central Asia as the real royal title. Ibn Battuta mentioned that "Khan" was the title of the Sultanate to the Mongol kings in Persia and Iraq. This title entered the Islamic world through the Khanate of Turkestan, as it was given to Prince Nasr bin Ali on coins in (390 AH / 999 AD) from Bukhara (Babajan, Pawl, Moamen, 1997) and in another from Ferghana in (399 AH / 1008 AD). It was then given to Alaa al-Din Abi al-Fath Muhammad bin Teksh Khwarizm Shah on coins in (610 AH / 1213 AD) from Samarkand and then moved to some parts of the Islamic world with the Turks and Tatars as a symbol of power, given to Abi al-Fath Tugrul al-Sultani on an inscription of foundation in (640 AH / 1242 AD) in Bary Dirka in Bihar in India and Ali bin Makarem "Tatar Khan" on an inscription of foundation in $665 \mathrm{AH}$, in the shrine of Shah Fadlullah in Bihar in India (al-Basha, 1984, p. 274).

The name Iskandar Khan follows a supplication for the continuation of his rule, raising his stand and the permanence of goodness. Perhaps this supplication belongs to Abdullah Khan, who ordered the establishment of the facility for the memory of his father, for Iskandar Khan died in $961 \mathrm{AH} / 1554 \mathrm{AD}$ before building the facility. Then whoever took over the supervision of the building was referred to in the form of (was established with the effort and supervision of Abd Balat al-Khalifa, may God bless him), where the name

of the construction supervisor was not entioned; perhaps he was humble to write his name next to the name of Iskandar Khan, for this statement suggests complete submission to the ruler, his great love for him and his surrender to him. 


\section{Inscription of Foundation dated 970 AH / 1562 AD at Jehar Bakr Mosque in the City of Bukhara}

Then the inscription ends in the date $970 \mathrm{AH}$, which represents the date of finishing construction and it is noted that the date was written in letters and numbers as is customary in most establishments in the region. Before the date, the statement (in a year) was written and neither the day nor the month was mentioned.

By reviewing the inscription of foundation, it is found that it indicates the completion of the construction of the mosque, and that the one who gave the construction order is Abdullah Khan, the ruler of Bukhari, for he was keen on registering his father's name Iskander Khan on the inscription of foundation not under the name of the construction order, as he gave him many titles that are characterized by diversity and distinctiveness, expressing his political and religious standing. It also reflects the loyalty of Abdullah Khan to his father Iskander Khan. The number of titles reached twenty-one, followed by the name of Iskander Bahader Khan, and then the supplication, ending the inscription with the date of ending construction.

\section{Results:}

The study confirmed the connection of rulers in that period in Central Asia with Sufis 'sheikhs, approaching them, consulting them, and establishing religious facilities bearing their names.

The study clarifies through the titles mentioned in the inscription the interests of some rulers in mental sciences, especially astronomy, among them Iskandar bin Abdullah Khan in Bukhara, and before him Mirza Alagh Beik in Samarkand.

The study confirmed the rulers' keenness to receive religious titles that clarify their religious duties, in addition to political, functional and honorary titles.

The study proved that the titles given to Iskandar Khan in the inscription under study, were not given for him as a matter of pride and glory, but rather related to what he did as religious and political achievements.

\section{References}

The Holy Quran

\section{First: Arabic Sources:-}

- Ibn Manzur (Muhammad bin Makram bin Ali), Lisan Al-Arab, Beirut, 3rd edition, 1994. Al-Jahiz (Abu Othman AmrIbn Al-Laithy), Al-Taj fe Akhlak Al-Muluk, Al-Amiriyya Press, Cairo, 1st edition, 1914.

Al-Jawhary (Abu Nasr Ismail bin Hammad), Al-Sahah, edited by Khalil Mamoun Shiha, Dar AlMaarefa, Beirut, First Edition, 2005.

Al-Farahidi (Khalil bin Ahmad), Kitab al-Ain, edited by Mahdi al-Makhzoumi, First Edition, 1994.

Al-Qalqashandi (Abu al-Abbas Ahmad bin Ali), died (821 AH / 1418 AD), Subh Al-Asha Fe Sna'aa al-Insha, Dar Al-Kutub Al-Alamia, Beirut, 1913.

Second: Arabic References:-

Al-BaBa (Kamel), Ruh al-Khat al-Arabie, Dar Lebanon for Printing and Publishing, First Edition, 


\section{Journal of Faculty of Archaeology - Volume 232020}

- Babacan (Bakhtiar), Powell (Jürgen), Moamen (Ashurbek), Shawahed Kbour al-Shaybani (Khwanyan Uzbeks), Publishing house: Dr. LudwikRehrt, Wiesbaden, 1997.

- Al-Basha (Hassan), Al-Alkab al-Islamiya fe al-Tarikh wal Wasaek wal Asar, Dar AlNahda AlArabiya, 1984, P P 274, 412.

Arslan, (Ali Alp), Al-Khat al-Arabyeind al-Atrak, translated by Suhail Saban, Al-Darah Journal, First Issue, 2007.

Arminius (Vambri), Tarikh Bukhara, translated by Ahmed Mahmoud Al-Sadaty, review and presentation of Yahya Al-Khashab, 2nd edition, 1987.

Akram (Al-Sayed Abdel-Mumin), Adwa ala Tarikh Turan, Turkestan, Presented by Ahmed

Muhammad Jamal, League of the Islamic World Press in Makkah, 1970.

- Bartold (Vasily), Tarikh al-Turk fi Asia al-Wusta, translated by Dr. Ahmed El-Suleiman,

Egyptian General Authority of Egypt, 1996.

-Barakat (Mustafa), Al Alkab wa alwzaef alosmania derasa fi tatawor Alalkab wa alwzaef monz alfath alosmani htta elkaa alkelafa alosmania (( min kelal Al athar wa alwthaek wa almaktotat, 1517 AH -1924 CE). Gharib House for Printing and Publishing, 2000.

- Gharmat (Hussein), the clear third line, aesthetic study in its design variations, Dar AlYanabee

', Damascus, 2016, P 39.

-Ghomaa (Ibrahim), a study of the art of the evolution of Kufic writings on stones in Egypt in the first five centuries of migration, with a comparative study of these writings in other parts of the Assyrian world, Dar Al-Fikr Al-Arabi, 1969.

Dawood (Maysa Mahmoud), Arabic writings on Islamic antiquities from the first century to the twelfth century of migration (7-18 AD), the Egyptian Renaissance Library, 1st edition, 1991 AD. -Daerat Al maaref Al Eslamia, Volume 3, published in Arabic by Ahmed El-Shentnawi, Ibrahim ZakiK horshid, Abdel Hamid Younis, 1913.

-Abd al-Khaliq (Abd al-Rahman), Alfekr Alsofi fi dooa alketab wa alsonna, IbnTaymiyyah Library, Kuwait, 2nd edition, 1984 AD.

-Ebaid (Shebl), Alketabat alathria ala elmaaden fi alasr altaimory wa alsfawi, first edition, Cairo House, 2002.

-.............Alnekosh al enshaeia fi madint Samarkand wa ahamiteha alathria, Research at the Conference of the Faculty of Arts - Minia University, 2005.

-........... Dewanalkatalarabi fi Samarkand, Library of Alexandria, first edition, 2012 AD.

-.............Alkat alkofi ala alamaier fi Asia alwosta alnasha wa altatwor, Center for Research and Historical Studies, Faculty of Arts, Cairo University, January, 2012 AD.

-Ebaid (Shebel), Hilal(Karim), Nakshwakfimoarahbisanat (1132 A.H / 1720 A.D) Madrasa shirkazi khan fi Khiva, King Saud University Journal, second issue, , 2013.

-Fadaely (Habib Allah), Atlas alkhatwaalkotot, translated by Muhammad Al-Tunji, Dar Tlas, Damascus, 2nd edition, 2006.

-The Arabic Language Academy, Almogam Al-Wajeez, the publisher of the Arabic Language Academy, 1989.

\section{Third, scientific theses- :}

-Essam (Dalia), inscriptions in the establishments of the city of Samarkand in the period of the Timurid rule (771-911 AH / 1369-1505 AD), manuscript unpublished master's thesis, Faculty of Archeology - Cairo University, 2013, P 107. 


\section{Inscription of Foundation dated 970 AH / 1562 AD at Jehar Bakr Mosque in the City of Bukhara}

-Ghaly (Noha Gamil), ceramic tiles and mosaics in Bukhara during the tenth and eleventh centuries AH / 16th and 17th centuries AD, manuscript of the Masters of Geography, manuscript unpublished master's thesis, Faculty of Archeology - Cairo University, 2011, P 58.

-Majdi (Maha), writings on stone and marble structures in the Timurid and Shaybani eras (771, $1008 \mathrm{AH} / \mathrm{1369}, 1599$ /) in the cities of Samarkand and the month of Sabz, manuscript master's thesis not published, Faculty of Archeology, Cairo University, 2018,P P 287, 354

Fourth: Foreign references;

- Ahmedov (Bo`riboy) , O`zbekistonda Arablar va Islom Toshkent,1996, P336.

-Blair ( Sheila), Islamic inscriptions , Edinburgh university press , 1998 .

- Zohidullo (munavvarov), The History of Central Asia from the period of Hukuman Dynasty

till now, Tashkent,2006.

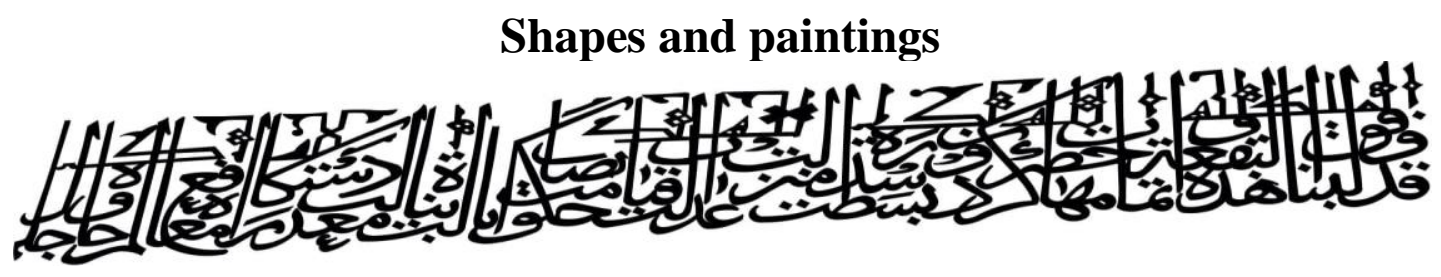

(A)

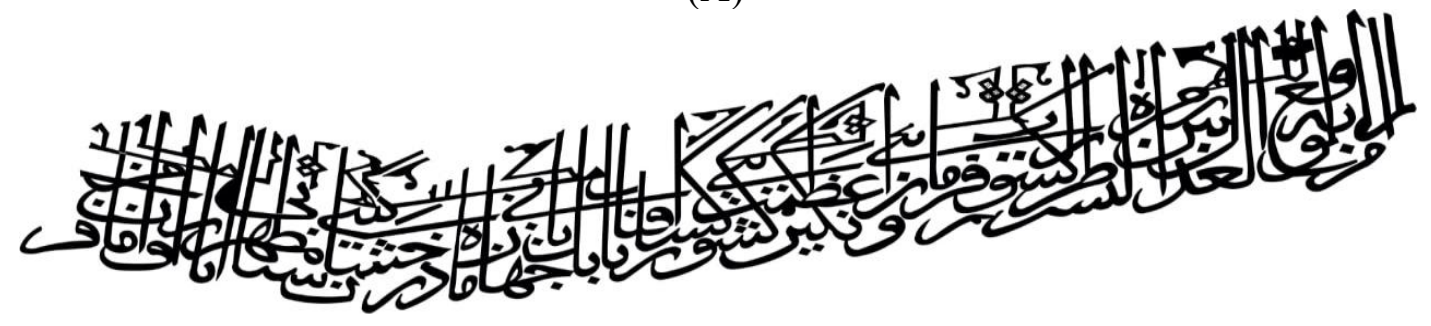

(B)

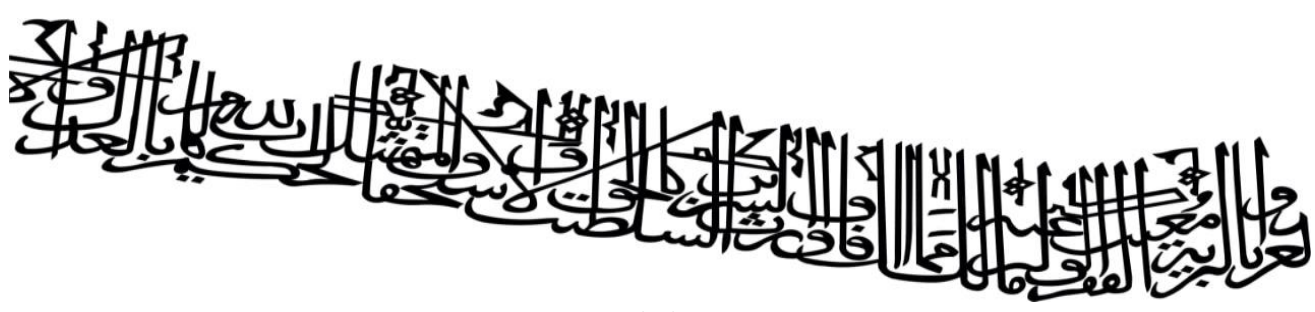

(C)

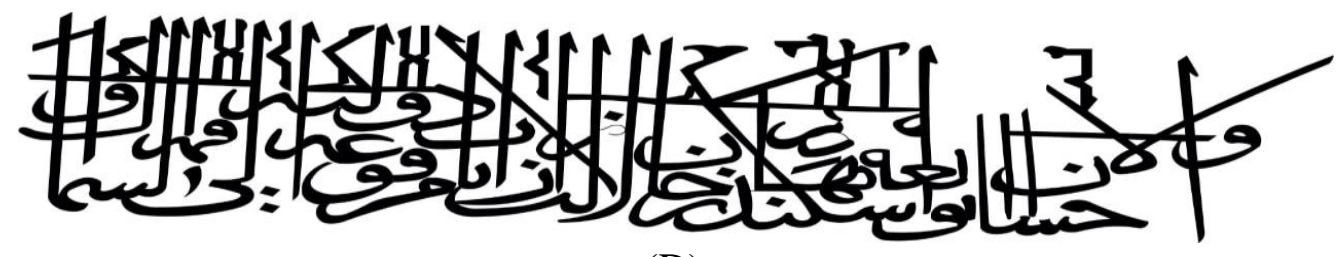

(D) 
Journal of Faculty of Archaeology - Volume 232020

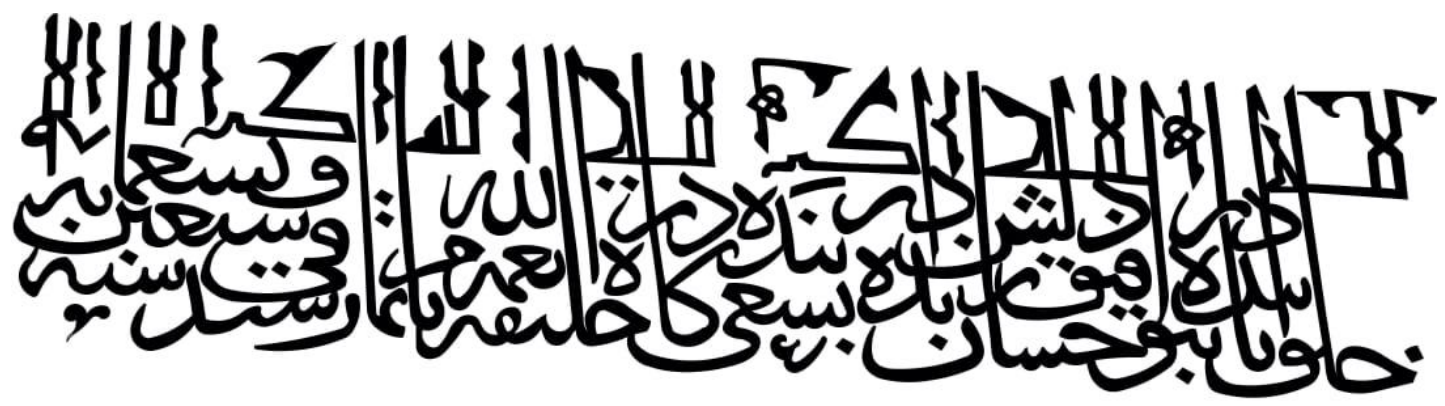

(E)

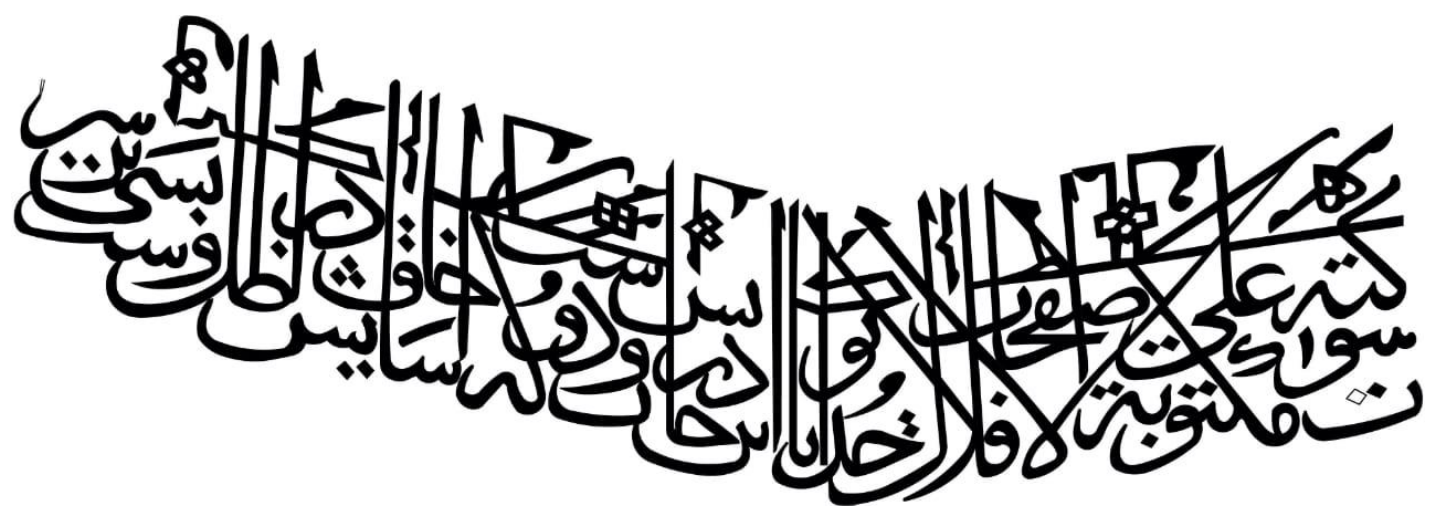

(F)

(Figure 1) illustrates the founding inscription of the main entrance block stone at the JaharBakr Mosque in the city of Bukhara

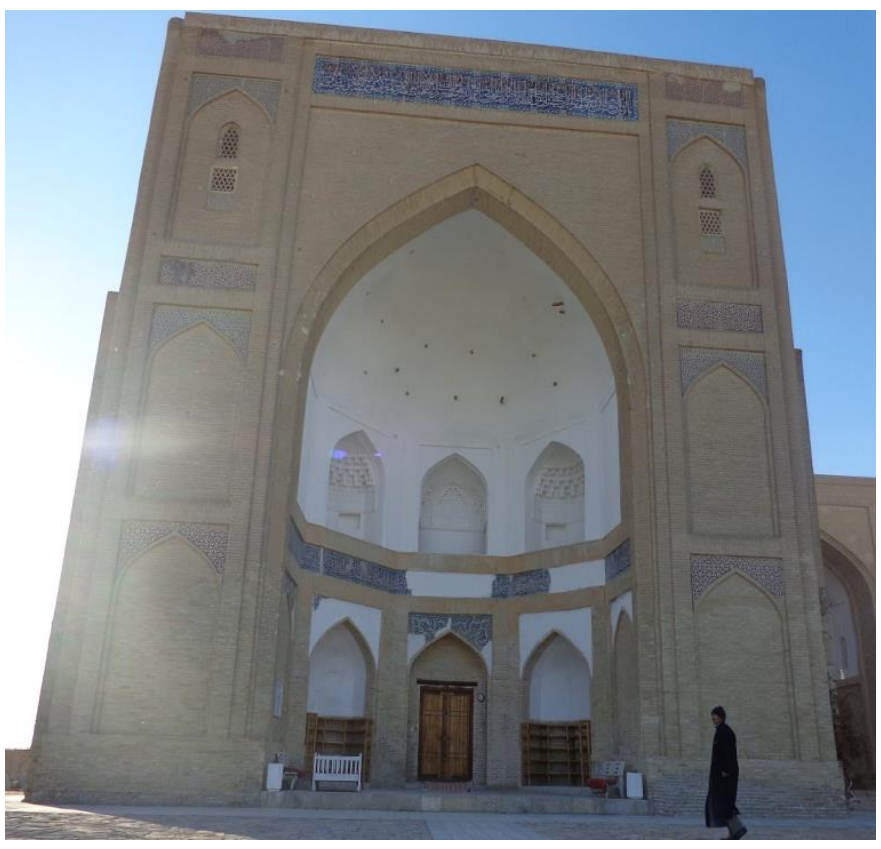

(P1 1) shows the main facade of JaharBakr Mosque in Bukhara 
Inscription of Foundation dated 970 AH / 1562 AD at Jehar Bakr Mosque in the City of Bukhara

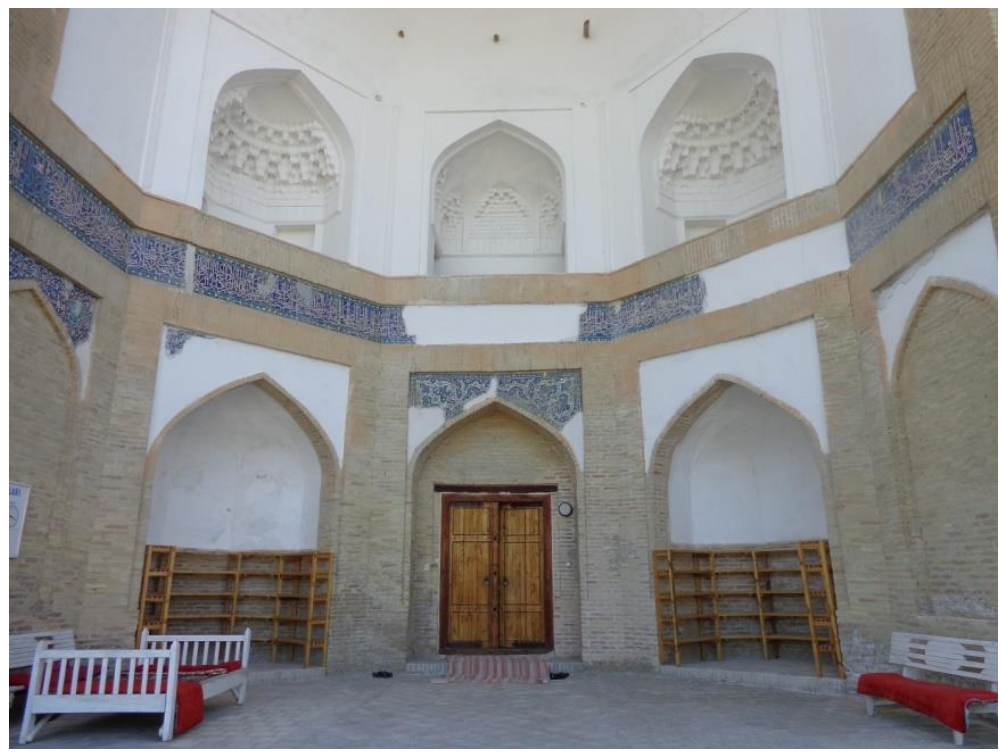

(P1 2) shows the founding inscription of the main entrance block stone

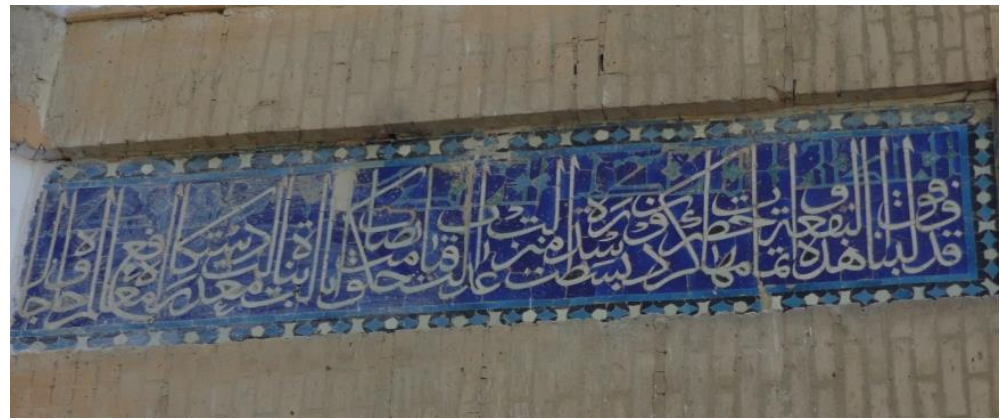

(Pl 3) illustrates the onset of the foundational segment

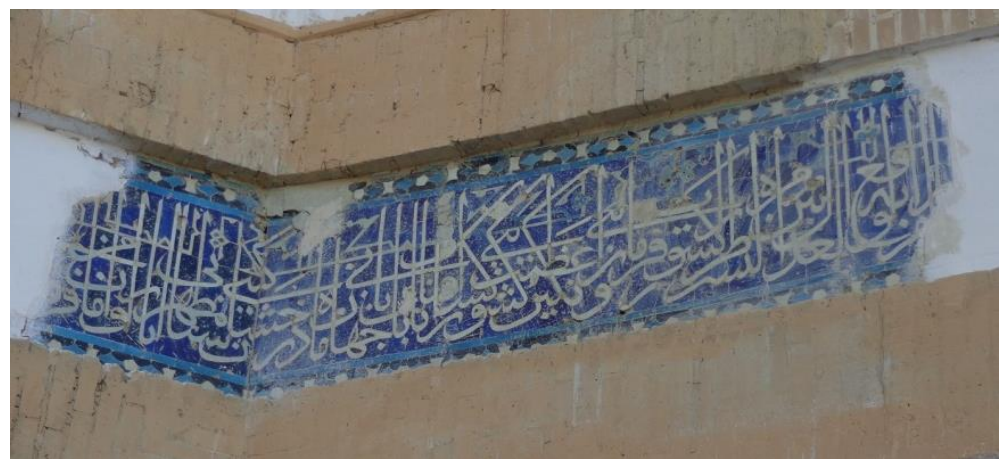

(Pl 4) detailing the founding inscription 45 
Journal of Faculty of Archaeology - Volume 232020

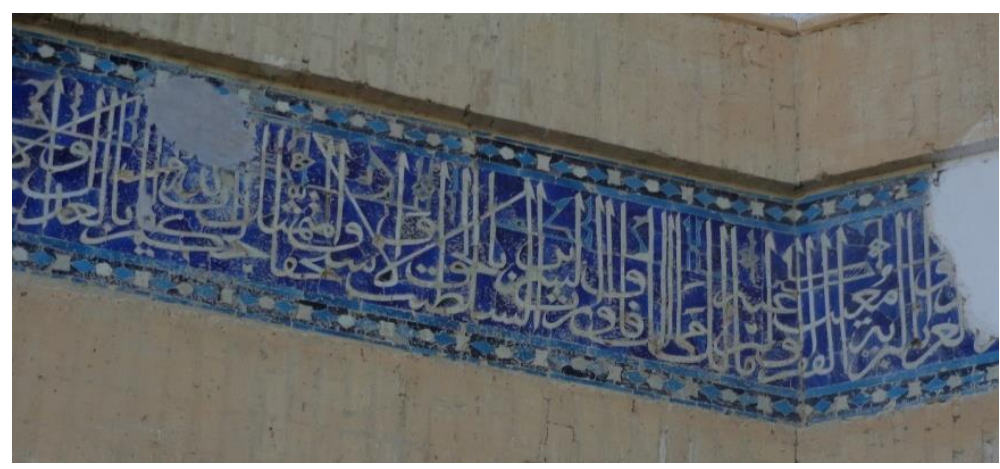

(Pl 5) detailing the founding inscription

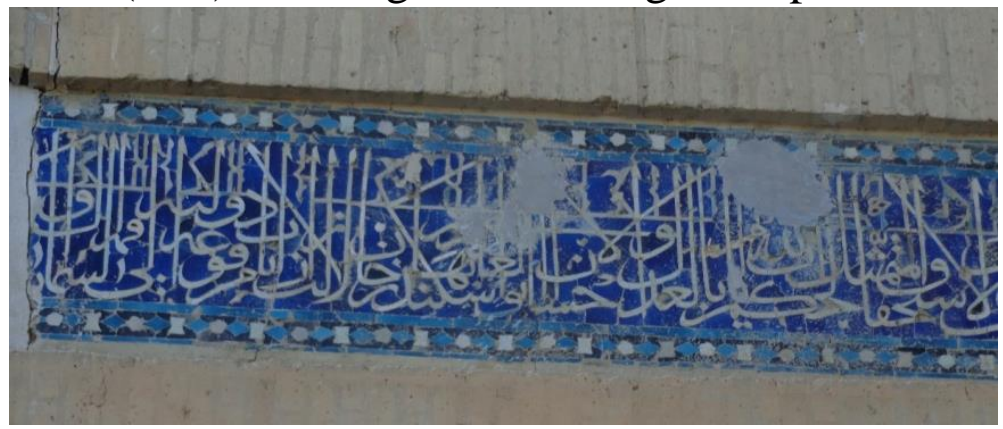

(P1 6) detailing the founding inscription

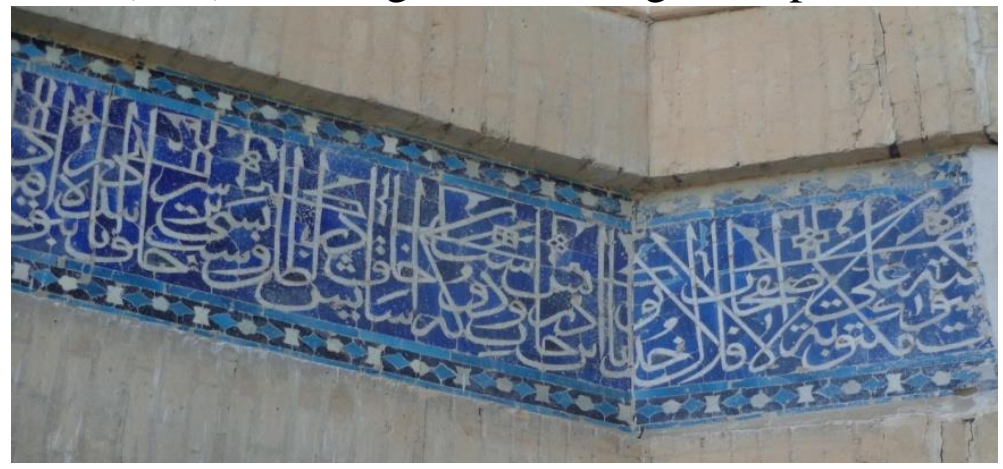

(P1 7) detailing the founding inscription

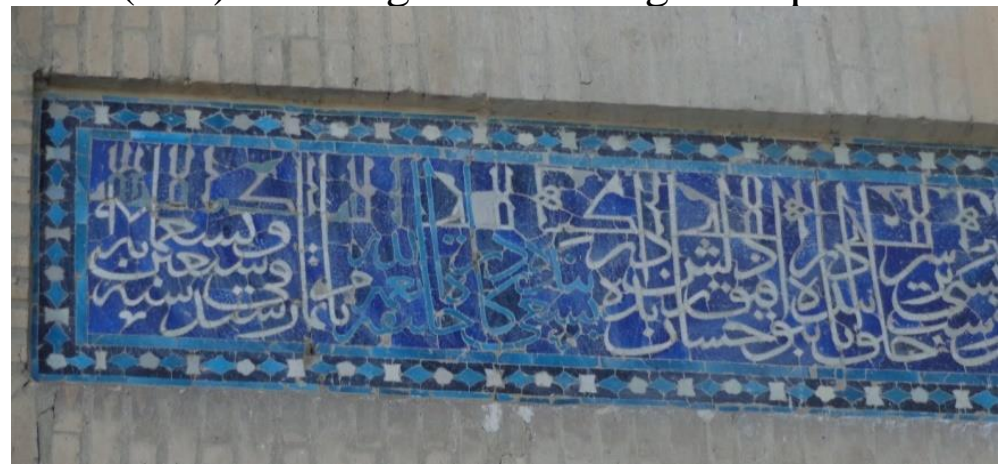

(Pl 8) illustrates the end of the foundation inscription 